\title{
SOME OBSERVATIONS ON THE HISTORY OF THE USE OF BARIUM SALTS IN MEDICINE
}

\author{
by
}

\author{
G. D. SCHOTT*
}

\section{INTRODUCTION}

THAT THE history of attempts aimed at introducing barium salts into medicine is both long and chequered is doubtless due to the highly beneficial yet also exceedingly poisonous qualities that were attributed to these compounds. The development of their use reveals an optimism in their healing powers as baseless as it was dangerous; and that more people did not succumb through the exuberance of zealous, if wellintentioned, doctors, and also through the occasional instances of mistaken identity that occurred in everyday life, must largely be ascribed to good fortune.

\section{PHOSPHORESCENT BARIUM SULPHIDE}

Three hundred years before the introduction of insoluble barium sulphate for gastrointestinal tract investigation (now the only common use of barium salts in medicine), the same substance was a recurring topic that occupied the attention of the alchemists over many years. ${ }^{1}$ The first mention of what we now know to be a compound of barium came from Italy. A shoemaker, Vincenzo Casciorolo, is said to have discovered phosphorescent barium sulphide in about 1602, when he obtained the sulphide from the native sulphate by a process of calcination. Casciorolo does not record this; indeed it is only some thirty years later that he is mentioned in two letters, published together in $1634 .^{2}$ One letter is by a Bolognese lawyer, Count Bisaccione, and the other by a doctor of medicine and professor at Bologna, Ovidio Montalbani. From these letters it is evident that by heating samples of local stone present in the mountains around Bologna, Casciorolo could obtain a substance that, having been exposed to sunlight during the day, glowed by night. In retrospect, the phenomenon is explicable by the conversion of the naturally occurring barium sulphate to phosphorescent barium sulphide.

This phosphorescent substance became the subject of intense interest in Italy and elsewhere, and was investigated by several authorities; a detailed account of its preparation appears in Potier's Pharmacopoea Spagirica, which makes brief reference to its property as a depilatory. ${ }^{3}$ Whilst on his travels, Evelyn records in his Diary that he met Montalbani, who showed him the phosphorescent stone; ${ }^{4}$ Montalbani noted that if the material was used externally it acted as a depilatory, and if taken internally caused vomiting. ${ }^{5}$ Fortunius Licetus, then Professor at Bologna, wrote extensively on the native stone and the phosphorescent substance derived from it; he,

*15 Park Avenue, London, NW11 7SL.

Medical History, 1974, vol. 18. 


\section{G. D. Schott}

too, refers to the depilatory properties of the latter, and adds that it is effective against even the toughest hair! ${ }^{6}$ It is interesting that barium sulphide is still listed as a depilatory in Martindale's Extra Pharmacopoeia, ${ }^{7}$ although it does not appear in the British or United States pharmacopoeias.

Owing to its proximity to what is now called Bologna, the substance from which the phosphorescent material was obtained was called Bolognan Stone, or Lapis Bononiensis. ${ }^{8}$ The phosphorescent material, which Casciorolo is said to have called Lapis Solaris, was known as Bolognan Phosphorus; both this and Hermetic Phosphorus (calcium nitrate) were the subject of a treatise by Christian Mentzel. In his book, Lapis Bononiensis in obscuro lucens, collatus cum Phosphoro Hermetico, there is a chapter relating to the calcined Bolognan stone, whose title includes 'de usu ipsius medico'; however the medical uses of the stone are summed up in only a few words, as being caustic, able to cause vomiting, and helpful in gout. ${ }^{9}$ The last property does not appear to have been borne out by subsequent experience.

\section{MINERALOGY AND TOPOGRAPHY OF BARIUM SALTS}

In former years, the mineralogy and topography played an integral part in the history and development of barium salts both in medicine and in toxicology. Barium is found in nature only in combination as salts, of which the sulphate and the carbonate are much the commonest. The sulphate occurs in spars, which by virtue of the heaviness imparted have been variously called barytes (barys: Greek-heavy), heavy earth or terra ponderosa; $;^{8}$ these spars have been found in Britain in such areas as Derbyshire, Cumberland and Cornwall, and other parts of the world including, of course, Italy. The carbonate, also known as Witherite (see below), is present in considerable quantities in Lancashire, Durham and Westmorland.

It is of interest that at the end of the seventeenth century, when the physician and naturalist, Charles Leigh, visited the lead mines near Andlesack (or Anglesark) in Lancashire, he noted that there were spars in the neighbourhood which if ingested could cause vomiting and purging. ${ }^{10} \mathrm{He}$ records, however, that the local inhabitants used to take the spars for 'Fits of the Stone' with good results, despite the vomiting and purging which the spars caused, and which he noted also worked 'violently by Urine' and 'causes the Diabetes . . .', doubtless due to the diuresis often associated with barium toxicity. Although Leigh did not know the active principle, which he ascribed to salt, sulphur and particularly arsenic, this region has a high content of barium carbonate, which probably accounted for the effects he described, and also for the deaths he recounts of one James Barns's wife and child, who died within nine hours of an excessive dose. The well-known chemist, Samuel Parkes, visited the same region over a century later ${ }^{11}$ by then, barium carbonate had been described, and Parkes was able to confirm the toxic nature of the spars also for sheep and ducks, the latter he thought mistaking the white substance for chalk or lime.

\section{LATE EIGHTEENTH-CENTURY THERAPEUTIC USES OF BARIUM SALTS}

The end of the eighteenth century saw the rise in the use of barium salts in medicine. Apart from the depilatory properties described by the Italians, there were probably no advocates of a therapeutic rôle for barium compounds until Adair Crawford, 


\section{Some Observations on the History of the Use of Barium Salts in Medicine}

Physician to St. Thomas's Hospital, wrote a detailed paper on 'The Medicinal Properties of the Muriated Barytes'. Although a preliminary report appeared in the Medical Commentaries in 1789 in the form of a letter to its Editor, Andrew Duncan, ${ }^{12}$ Crawford's treatise appeared a year later in the Medical Communications. ${ }^{13}$ In this treatise are described the highly beneficial effects of the muriated barytes (barium chloride) on several pathological conditions, which probably included a variety of scrophulous lesions, malignancy, osteomyelitis and venereal disease. He treated fourteen cases with good results (nearly all with the desired diuretic accompaniment), and impartially records three scrophulous cases in which treatment was ineffective, and which he ascribed to the advanced stage of the disease. The barium chloride, given orally, was generally employed as a treatment of last resort, often in association with other medicaments, which in one case included mint water, spirit of lavender and powder of columbo root. Apart from the often associated diuresis and laxity of the bowels, he noted an increased secretion from the skin; larger doses caused nausea, vomiting, purging and occasionally vertigo. Prudently, he commented (p. 347) 'like every other active medicine, it would no doubt, if administered injudiciously, be capable of producing deleterious effects', but fortunately no serious misadventure occurred. There is also a delightful discussion of the contaminants tending to be present in the muriated barytes-copper, lead, arsenic and particulary iron-and of methods for detecting the impurities and the proper processing of the native heavy spar.

Over the succeeding decade, there appeared on the continent several works on the therapeutic properties of barium salts. ${ }^{14}$ Perhaps one of the most detailed was that by Hufeland, Court Physician at Weimar, who acknowledged Crawford's precedence in introducing the compounds of barium into medicine. Hufeland's book on the clinical use of barium chloride, ${ }^{15}$ which appeared in 1794, is remarkable. In it, he extols the value of barium in an enormous range of scrophulous conditions, and he also attributed to scrophula various eye, skin and scalp diseases and headaches, as well as glandular enlargements and induration, haemoptysis and incipient phthisis. Hufeland further strongly recommended the use of barium chloride as an antihelmintic, and for gastrointestinal obstruction, asthma, rickets, scabies (when, as with other skin disorders, he employed the medicament both internally and externally), and for a large number of other disease states, which included 'suppressed monthly cleansing' (presumably amenorrhoea) and insanity (an indication he quotes from another source). Barium salts, he avers, are an undoubtedly important remedy in children's diseases, and have a place amongst the materia medica next to tartar emetic and antimony wine. He reassures the reader that the chloride is hardly poisonous for normal people; hysteria and other pathological conditions cannot be considered as yardsticks! He was also bold enough to use barium chloride topically for diseases of the cornea.

Hufeland's book was widely quoted at the time, and other authors' claims for the efficacy of the barium salts were no less extravagant. James Clark, who practised in Santo Domingo, described in 1791 the use of the terra ponderosa muriata (the chloride) in a 'peculiar Species of Scrophula, occurring among Negroes in the West Indies', characterized by extensive superficial ulceration and glandular enlargement of 


\section{G. D. Schott}

both extremities. ${ }^{16}$ One can scarcely speculate on the aetiology of the disease, but Clark states the appearances were not of venereal disease or yaws; in two people, cure was effected within four months. Clark also reported that he was attempting the treatment of leprosy with barium chloride. A year later an anonymous contributor to the Medical Commentaries confirmed the ameliorating effect of the chloride in scrophula, but unfortunately the benefit derived could not prevent an ultimately fatal outcome. ${ }^{17}$

\section{TOXIC EFFECTS OF BARIUM SALTS}

At the beginning of the nineteenth century, barium salts had a firm place amongst medicaments used in Britain as well as in Germany. The 'benefit' was to extend still further, and, according to Pelletier, ${ }^{18}$ by 1796 barium chloride was already being prescribed by French physicians, and he urged great caution in its use. Schwilgué in his Traité de Matière Médicale, $1809,{ }^{19}$ writes of the value of the chloride, both as solid and in solution, for scrophula, scirrhous tumours, chronic lung and skin diseases, tuberculous mesenteric adenitis and also for accelerating wound healing. The efficacy of barium chloride in treating scrophulous joint lesions was again noted some years later in a dissertation by Pirondi, which was critically reviewed in the Parisian medical press. ${ }^{20}$ Schwilgué remarks, as others before him, on the diuresis and increased perspiration associated with treatment, and interestingly comments that in the event of an excessive dose being administered, as evidenced by anxiety, nausea, vomiting, colic and other abdominal symptoms, treatment should be commenced with mucilages, diluted milk, lukewarm water and soups; barium sulphate he considered no less dangerous than the chloride, presumably because of the presence of soluble barium salts contained as impurities. He wisely writes: 'Son administration exige d'ailleurs la plus grande prudence, et son usage prolongé peut donner lieu à des accidens plus ou moins graves.' [Its administration demands, however, the greatest caution, and its prolonged use could give rise to very grave or slight accidents.]

Schwilgués remarks were well founded. Twenty years earlier in 1790, the same year as Crawford's report, James Watt, junior, was performing possibly the first animal experiments with barium salts. He reported his observations to the Literary and Philosophical Society of Manchester, in a paper entitled 'On the Effects produced by Different Combinations of the Terra Pondersosa given to Animals'. ${ }^{21}$ This paper is of considerable interest for a number of reasons, and must have been widely read, for a summary appeared in Germany the following year. ${ }^{22}$ Watt's curiosity was aroused by Leigh's comments on the spars of Anglezark: he recognized a strange similarity between the tales he himself had heard from the Anglezark miners, that they used the aerated barytes (barium carbonate) locally as rat poison, and Leigh's description of the poisonous qualities of those spars. Watt wrote: 'I therefore had little doubt that this must be the spar ... . alluded to [by Leigh]. And though some of its effects appeared to be exaggerated ... yet the subject seemed well worthy of a nearer investigation. For as poisons, when properly administered, are generally esteemed the most efficacious remedies . . . it appeared desirable to trace, upon inferior animals, the effects of a substance which promised to be of importance to the health of mankind ...; ; and he performed several experiments on dogs. During 


\section{Some Observations on the History of the Use of Barium Salts in Medicine}

one of these, he says he 'administered to a Terrier bitch . . . one drachm of Aerated Barytes, finely pounded and strewed upon some boiled beef, to induce her to take it.' An hour afterwards, 'she began to be slightly convulsed ... . but appeared very lethargic', and two hours later 'her debility kept gradually increasing, until a complete Paralysis took place . . . She succumbed some hours later. The observation of the paralysis is of significance, as will be mentioned below. In other experiments, Watt also observed the gastrointestinal symptoms, convulsions, restlessness and anxiety typical of barium poisoning, and found similar features on administration of the chloride and nitrate.

Watt's report encompasses three famous people of that era. Having performed research on-animals, he wished to carry out some chemical experiments on the Ponderous Earth, for he was 'of opinion, notwithstanding Dr. Withering's and Dr. Priestley's experiments, that the fixed air might be expelled from the Aerated Barytes by a strong heat alone, and sent some of it to Mr. Josiah Wedgwood, junior, requesting him to expose it to the greatest possible heat in one of his father's furnaces . . . Priestley, the illustrious chemist of that period, still believed in the prevailing phlogiston theory. The Dr. Withering referred to is the renowned William Withering, who discovered barium carbonate (in whose honour it is known as Witherite) and performed numerous chemical investigations on barium-containing rocks, which he reported in 1784, ${ }^{23}$ a year before his classic account of the foxglove. ${ }^{24}$ Josiah Wedgwood, junior, to whom Watt entrusted his Ponderous Earth, was the second son of the celebrated Josiah Wedgwood. This famous potter had worked for some years to find a paste of fine texture in an attempt to make a unique type of porcelain. He found materials for such paste in the earths from various regions of Lanarkshire, and from 1773 had experimented with both barium carbonate and sulphate, which were their significant constituents. The sulphate, in particular, became the chief component of his Jasper that was to become a milestone in ceramic art. The components of this unique pottery were initially secret, until by chance the secret came into the hands of a 'faithless servant', who sold the secret to Wedgwood's rivals. ${ }^{25}$

Four years after Watt's experiments on dogs, toxic effects were recorded in detail in a patient, perhaps for the first time, although it will be recalled that the Italians noted some ill effects of their spars. In 'An account of the Effects of an over-dose of the Terra Ponderosa Muriata', a 'Mr. A. Mather, Surgeon' described in 1794 the striking features of barium poisoning. ${ }^{26}$ The case is recounted of a gentleman 'subject to frequent attacks of colic', who considered his 'stomach much strengthened . . . by the terra ponderosa muriata, in doses of 10 or 12 drops, three times a day.' This unfortunate gentleman took by mistake six times the usual dose, and the effects are quoted in the sufferer's own words: ' . . . I began to be violently purged without griping, and, at the same time, began to be very much relaxed . . . the use of my limbs was gradually taken from me . . . I could not produce the least possible motion, in any joint or limb about me. The last part I lost the use of was my left hand.' After about a day, during which time he had been given camomile tea, gruel and tincture of guaiacum, and had had hot bricks applied to his 'deadly cold' feet, his recovery began, and was complete after a further day.

This case report appeared in the same year as did Hufeland's book on the efficacy 


\section{G. D. Schott}

of the same substance, and over the succeeding decades, views on the healing powers of barium gradually gave way to an acknowledgement of the lethal nature of nearly all the compounds, as further instances of poisoning were recorded. A case was notified in 1818 in which a girl took barium chloride in mistake for Glauber's salts; she felt as if she was on fire, vomited, convulsed, became deaf and was dead within an hour. ${ }^{27}$ This type of incident was to recur on many occasions. Blyth, writing in $1884,{ }^{28}$ could find only fifteen cases on record of barium poisoning, but this may have been an underestimate, since Bary in 1888 found nineteen cases (with twelve deaths), and Kobert by 1906 had collected thirty cases (with twenty deaths). ${ }^{29}$ In any event, it is evident that though cases of poisoning were relatively infrequent, the incidents were all the more tragic since the majority were due to barium salts taken in mistake for other substances. For instance, in 1868, baryta was given with fatal results to an eighty-two-year-old man instead of 'milk of sulphur' (calcium sulphide). ${ }^{30}$ There was a suspicion that it had been given intentionally by the elderly man's landlady, but the coroner and jury decided the fault lay with a Mrs. Hills, who had sold the substance at the chemist's shop-the landlady was exonerated, and of Mrs. Hills, the coroner 'expressed his firm conviction of her unfitness to keep a chemist's shop.' Heavy baryta sizing salts (possibly a form of barium hydroxide), used in the Manchester area to strengthen cotton warps, were taken in error for Epsom salts; after vomiting and developing paralysis, the unfortunate imbiber succumbed. ${ }^{31}$ More recently, a woman died who had been given barium chloride as 'health salts'. The neighbour who had provided the substance knew nothing of the nature of the supposed health salts, except that her husband had brought them into the house and used them as a footbath. ${ }^{32}$ Barium compounds have also been taken in error for Rochelle salts, ${ }^{33}$ common salt, ${ }^{34}$ and sulphur ${ }^{35}$ they have in addition been taken with suicidal intent ${ }^{36}$ and to procure an abortion. ${ }^{37}$

Cases of mass poisoning have also occurred, and are of interest because the sometimes temporary paralysis, typical of barium toxicity, is a frequent accompaniment. Probably the first such incident was that described in 1922 by Higier in Warsaw, ${ }^{88}$ and illustrates how poisoning of large numbers of people may arise. There were several cases in which, after an onset characterized by abdominal symptoms, a profound and flaccid paralysis developed, although sensory and sphincter functions remained unimpaired. The symptoms in most cases had virtually resolved within twenty-four hours. In one episode, members of the same household became ill (one fatally), as did the assistant from the local baker's shop. Smuggling was rife at that time after wartime shortages, and it eventually became apparent that the cause of the outbreak was adulteration of smuggled flour with a variety of barium salts, which thereby increased the weight of the flour. Higier included a detailed case history, and found inexcitability of skeletal muscle by both direct and indirect stimulation, thus implicating the muscle itself as the affected organ. Very remarkably, and for the first time, Higier noted the considerable similarity between the paralysis that barium may cause and that occurring in the rare genetic disease of familial periodic paralysis, a disease that was becoming increasingly recognized and delineated at that time..$^{39}$

A probably independent observation of the similarity between barium poisoning and familial periodic paralysis was made some twenty years later by Huang, ${ }^{40}$ in one 


\section{Some Observations on the History of the Use of Barium Salts in Medicine}

amongst a series of papers commencing with that by Allen, ${ }^{41}$ which appeared in 1943 in the Chinese Medical Journal. The reports were prompted by finding numerous people in the Szechwan province of western China who suffered mild gastrointestinal symptoms associated with usually transient, but sometimes fatal, paralysis. The disease, for years endemic particularly in the region around the town of Kiating, was known locally as Kiating paralysis, or Pa Ping (soft disease). Allen and his colleagues traced the cause to the very high barium chloride content in the soil, and the table salt in that region was found to be naturally 'contaminated' by up to twenty-five per cent barium chloride. Huang ${ }^{40}$ was the first to comment on the beneficial effect on the paralysis of potassium (citrate) administered intravenously, and the basis for this therapy has been made more secure over the past decade by the demonstration of the low plasma potassium concentration that frequently accompanies paralysis. ${ }^{\mathbf{4 2 , 4 3}}$ (It is of interest that poisoning does not seem to have occurred in Britain in places where there are relatively large amounts of barium; on the contrary, high quantities were supposed to be beneficial, and in 1894 an editorial from the Lancet laboratory reported that the therapeutic waters of Llangammarch contained barium salts in a concentration of 6.5-6.8 grains per gallon. ${ }^{44}$ )

Further episodes of large numbers of people becoming ill through contaminated food have been reported. In 1945, barium carbonate incorporated accidentally into the pastry of treacle and marmalade tarts was consumed by eighty-five British soldiers in an area of the Persia/Iraq Command;45 and in 1963, over 100 people were affected who had eaten sausages containing barium carbonate instead of potato-meal:46 in both outbreaks gastrointestinal and paralytic symptoms were a marked feature. Confusion has arisen on several occasions by the common use as a rat poison of barium carbonate, which closely resembles flour. Barium carbonate has been used for this purpose for well over two centuries, and was well known to James Watt; addition of a dye to prevent confusion is not always successful, since the rats may be more than equal to the challenge. ${ }^{47}$

\section{USE OF BARIUM SALTS IN MEDICINE}

During the present century, there have been two major developments involving the use of barium salts in medicine. One, the use of barium chloride in the treatment of heart block, was evanescent. The other, the introduction of barium sulphate in the radiological investigation of the gastrointestinal tract, was to prove an important and long-lasting contribution to medicine.

Initial work on the effect of barium on the cardiovascular system antedates the clinical application, albeit temporary, by a century. The irregular pulse frequently induced by barium was noted by Benjamin Brodie in animal experiments in 1812.48 He wrote with regard to barium chloride applied topically to wounds made in a rabbit: 'The pulse beat 150 in a minute, but feeble, and it occasionally intermitted'; and he, too, observed that paralysis could occur. Some of his work was quoted in the extensive article on barium compounds in Orfila's classic textbook of toxicology, Traité des Poisons (1814), ${ }^{49}$ which was translated into English in 1816. (Interestingly, Orfila reports that he was unaware at that time of any case of human barium poisoning, although in fact such cases had been described.) 


\section{G. D. Schott}

The hypertension that accompanies the systemic administration of barium was observed by Blake in $1841,{ }^{50}$ and he confirmed his findings in further experiments on dogs in $1874 .^{51}$ Schedel is said to have introduced barium compounds into Germany in 1903 as drugs to elevate the blood pressure in man, an alarming venture that was presumably unsuccessful. ${ }^{52}$

Great names such as those of Lauder Brunton ${ }^{53}$ and Sidney Ringer have also been associated with experimental work with barium compounds. Sidney Ringer, in collaboration with Harrington Sainsbury, noted the apparent similarity between barium and digitalis on the heart, and the spasm of arterioles induced by direct application of barium salts. ${ }^{54}$ The latter observation may have been the rationale for attempts reported in 1888 similarly to constrict the dilated veins associated with certain diseases: such attempts on the enlarged veins of the caput medusa in a patient with a renal tumour, and of the veins of the leg in a patient in cardiac failure, were unfortunately abortive. ${ }^{55}$

Although the occasional report of the employment of barium compounds for the treatment of heart disease had appeared, ${ }^{56}$ the introduction of these compounds into cardiology was largely due to Cohn and Levine. In 1925 they described the efficacy of barium chloride in increasing the heart rate in certain cases of complete heart block. ${ }^{57}$ Subcutaneous adrenaline, though valuable, was transient in its action, and Cohn and Levine reported favourably on the use of oral barium chloride in three patients with slow heart rates causing 'Adams-Stokes Disease'. Their work was based on the experiments of the prominent Viennese workers, Rothberger and Winterberg, who found that barium in the correct dose caused increased ventricular automaticity of the dog heart. ${ }^{58}$ Barium chloride was employed extensively in the treatment of Stokes-Adams attacks in America and Europe for some years, but in view of the development of far safer and superior drugs, this treatment has become obsolete.

The outstanding contribution of barium salts to medicine today is the use of the sulphate as a contrast medium in radiological investigation of the gastrointestinal tract. The safety of the sulphate lies in its great insolubility and hence lack of absorption from the alimentary tract. This was known at least as long ago as 1824, when Gmelin demonstrated the innocuousness of oral barium sulphate administered to animals, compared with the lethal effects of the soluble carbonate and chloride..$^{59}$ In connexion with the insolubility and harmlessness of the sulphate, an important paper by Boehm ${ }^{00}$ that appeared in 1875 on the physiology and pathology of barium poisoning reports on a dispute, as delightful as it was ingenious, about the way in which barium acted. The protagonists were Onsum (1863) who considered that poisoning by soluble barium salts was due to the formation of insoluble barium sulphate emboli in the blood vessels, ${ }^{61}$ and Cyon (1866) who was unable to find any evidence of emboli, and hence for this theory. ${ }^{62}$ Present evidence would favour Cyon's contention, but the problem that existed then exists today: Smith, Winkler and Hoff in 1940 were equally puzzled that soluble barium salts in concentrations small enough to be completely precipitated by the body could yet prove highly toxic. $^{\text {es }} \mathrm{A}$ further demonstration of the harmlessness of the sulphate is provided by the pneumoconiosis that occurs amongst the miners of ores containing barium sulphate. Inhalation of dust from these ores results in dense, radio-opaque shadows 


\section{Some Observations on the History of the Use of Barium Salts in Medicine}

in the chest $X$-ray, but the condition is entirely benign. First reported amongst Italian miners in 1933 by Arrigoni, ${ }^{64}$ it is possible that these miners' ancestors were engaged in the making of the Bononian phosphorus three centuries earlier.

The development of barium sulphate as a contrast medium evolved from the prior use of bismuth preparations. Although Cannon described the use of bismuth subnitrate in $1898,{ }^{65}$ a search was made for other substances, in view of the toxicity of the nitrate component (which via its conversion to nitrite, gave rise to methaemoglobin in the body), and later due to the scarcity of bismuth. Initially dismissed by Kaestle in 1908,66 barium sulphate was introduced into medical practice largely through the work of Krause, Director of the University Medical Clinic at Münster in Westphalia and of the Bonn Polyclinic. He read a paper at the Radiological Congress in 1910, and subsequently the first report advocating barium sulphate as an opaque contrast medium for use in radiology appeared in the same year, written by two of Krause's colleagues, Bachem and Günther. ${ }^{67}$ No sooner had barium sulphate made its debut than cases due to apparent toxicity began to be reported. It is said that Krause personally satisfied himself of the safety of the new substance when a case of poisoning became known to him, ${ }^{68}$ but nevertheless several, sometimes catastrophic, episodes of mistaken identity were to occur. These episodes in radiological work were sufficiently serious that, as early as 1919, two cases in which barium sulphide and carbonate had been incriminated were the subject of an annotation in the Lancet. ${ }^{68}$ However, as recently as 1950 , seven patients, one of whom died, received barium carbonate in mistake for the sulphate. ${ }^{70}$

\section{TOXIC EFFECT ON LIVESTOCK}

As will have been seen above, man is not the only animal to be affected by the soluble salts of barium, and a more bizarre episode of historical interest occurred in the United States and affected livestock. Ever since 1849, when the Indians along the Missouri River described to the immigrants a plant that produced death preceded by excitement in horses and cattle, it was known that certain plants of the pea family could cause disease if eaten by horses, cattle, sheep and a variety of other animals. Those affected frequently died of the so-called 'loco' disease, the term 'loco' being derived from the Spanish for foolish or crazy. The animals which had fed on the 'loco plants' or 'crazy weeds' developed alimentary disturbance, with malnutrition and emaciation, became sluggish and unco-ordinated, and had difficulty in moving; they became progressively more afflicted, with dullness, stupor and maniacal episodes, and frequently died. As a result, there was a large loss of this valuable livestock. The United States Department of Agriculture set up research to investigate the problem, which was carried out by a pharmacologist, A. C. Crawford, and his exhaustive report ${ }^{71}$ which appeared in 1908 and was the subject of a leading article in the Journal of the American Medical Association of the same year, ${ }^{72}$ revealed that 'loco' disease was caused by chronic (and rarely acute) barium poisoning, due to ingestion by the animals of barium salts present in certain species of plants. The soil, however, did not contain large quantities of barium, and Crawford considered that the plants must collect and store minimal amounts of barium. Paradoxically, the plants that gave rise to 'loco' disease were known to have been used for medicinal 


\section{G. D. Schott}

purposes by the Chinese for very many years, ${ }^{73}$ although of course whether they contained significant amounts of barium (known for over a century to be toxic to plants ${ }^{74}$ ) is not reported.

\section{CONCLUSION}

It is evident that throughout the history of barium in medicine there has been a very close relationship between the therapeutic and the toxicological aspects, frequently the latter playing a more prominent part; in addition, there has existed a concurrent background of physiology and pathology. It seems appropriate to conclude with the comments of earlier workers on the therapy for the ill effects that all too readily became manifest. Orfila commented 150 years ago that soluble sulphates should be prescribed in any case of barium poisoning encountered (and it will be recalled that he was unaware of any report of this), provided they were administered quickly, and before the barium had been absorbed in sufficient quantity. ${ }^{49}$ This, he states and probably correctly, would precipitate the barium as the insoluble sulphate, and he supported his views by an experimental observation on a dog. He recommended Glauber's or Epsom salts. The advice he gave is still valid today. ${ }^{75}$ In the past, treatment has been quaint-tincture of guaiacum, ${ }^{26}$ dramatic-Epsom salts enemas and strychnine, ${ }^{33}$ and recently more rational. Following the lead of Huang, the first to note the beneficial effect of potassium salts in his cases treated with intravenous potassium citrate, ${ }^{40}$ others have also found potassium salts beneficial, possibly even if administered orally..$^{45}$ There is today experimental evidence that in addition to correction of the low plasma potassium state frequently prevailing, benefit may be obtained from drugs that control the irregular heart action that barium often causes, and which may give rise to some of the fatalities. ${ }^{76}$

The soluble barium salts have now rightly been relegated to history with regard to their place in medicine. Currently there remain the rare use as a depilatory of barium sulphide (a property of the Bolognan Phosphorus known three hundred years ago), and also the use of barium sulphate, the Bolognan Stone, employed so extensively in radiology. Both the sulphide and the sulphate featured prominently in the history of alchemy during the seventeenth century, and the present observations have primarily concerned the vicissitudes associated with attempts to introduce these and other compounds of barium as therapeutic substances for man.

\section{ACKNOWLEDGEMENTS}

It is a pleasure to acknowledge my gratitude to Dr. B. McArdle, who first stimulated my interest in barium and its properties; and to my father, Dr. A. Schott, for encouragement and invaluable advice.

\section{REFERENCES}

1. Partington, J. R., A History of Chemistry, London, Macmillan, 1961, vol. 2, pp. $334-40$.

2. Letters by $M$. Bisaccione and $O$. Montalbani, published together in Bologna, 1634, (owned privately)-see Partington, op. cit., p. 336.

3. Potier, P., Pharmacopoea Spagirica. Id est, nova et inaudita rariora et efficacissima ad gravissimos quosque morbos Remedia conficiendi ratio, Cologne, M. Smitz, 1624, p.407. 


\section{Some Observations on the History of the Use of Barium Salts in Medicine}

4. Evelyn, J., Diary, May 1645, ed. by E. S. de Beer, Oxford, Clarendon Press, 1955, vol. 2, pp. 422-23.

5. Montalban, O., see Partington, op. cit., p. 336.

6. LicETUS, F., Litheosphorus, sive de Lapide Bononiensi lucem in se conceptam ab ambiente claro mox in tenebris mire conseruante liber, Utini, N. Schiratti, 1640, p. 102.

7. Martindale, William, The Extra Pharmacopoeia, 26th ed., edited by N. W. Blacow, London, The Pharmaceutical Press, 1972, p. 477.

8. The terminology relating to barium and its salts is confusing. The Oxford English Dictionary and the Lexicon of Medicine and the Allied Sciences (compiled by $\mathbf{H}$. Power and L. W. Sedgwick, London New Sydenham Society, London, 5 vols., 1881-1899) give considerable information. Thus baryta (or barita) was the name frequently given to barium oxide; hence baryta water (barium hydroxide). Barytes, although an obsolete term sometimes used for baryta, most commonly refers to native barium sulphate. This sulphate, on account of its heaviness, was known as terra ponderosa, heavy spar, Schwerspat(h), etc., and also in various regions as cauk. It is presumably identical with Bolognan Stone or Lapis Bononiensis. When this barium sulphate was ignited in the presence of charcoal and placed into a sealed tube when hot, it shone in the dark-the substance produced was Bologn(i)an Phosphorus or Kercher's Phosphorus, and probably is the same as Lapis Solaris; it is barium sulphide. Hermetic Phosphorus is calcium nitrate (see Partington, op. cit., p. 338). Sir Humphry Davy, who first separated the element in 1808, purposely discarded the second syllable of baryta, in an attempt at uniform nomenclature of the elements.

9. MeNTZEL, C., Lapis Bononiensis in obscuro lucens, collatus cum Phosphoro Hermetico ... Christiani Adolphi Balduini . . . nuper edito, et cunctis Naturae Indagatoribus ulterioris scrutinii ergo exhibitus . . ., Bielefeld, J. Trenckenerus, 1675, pp. 68-73.

10. LeIGH, C., The Natural History of Lancashire, Cheshire, and the Peak, in Derbyshire: with an account of the British, Phoenician, Armenian, Gr(eek) and Rom(an) Antiquities in those parts, Oxford, 1700, pp. 70-71.

11. Parkes, S., Chemical Essays, principally relating to the Arts and Manufactures of the British Dominions, 2nd ed., London, Baldwin, Cradock \& Joy, 1823, vol. 1, pp. 313-62.

12. Crawford, A., Letter to Dr. Duncan, Medical Commentaries, 1789, 4, 433-36.

13. CraWford, A., Medical Communications, 1790, 2, 301-59.

14. For references to early treatises on the use of barium in medicine, see: C. W. Hufeland (ref. 15), p. 2; and E. J. Waring, Bibliotheca Therapeutica, London, New Sydenham Society, 1878, vol. 1, pp. 285-86.

15. HufBLAND, C. W., Vollständige Darstellung der medicinischen Kräfte und des Gebrauchs der salzsauren Schwererde, Berlin, Rottman, 1794.

16. Clark, J., Medical Commentaries, 1791, 6, 267-70.

17. Ibid., 1792, 7, 466-72.

18. Pelletier, P. J., J. nat. Philos., Chem. Arts, 1798, 1, 529-34.

19. Schwilgut, C. J. A., Traité de Matière Médicale, 2nd ed., Paris, Brosson, 1809-1812, vol. 1, pp. 407-10.

20. PIRONDI, S. [Thesis], De la tumeur blanche du genou, Montpellier, 1833; reviewed in Gaz. méd. Paris, (2nd series), 1834, 2, 239-40.

21. WatT, J., Mem. Proc. Manchr lit. phil. Soc., 1790, 3, 609-18.

22. GIRTANNER, Medicinische Bemerkungen, in: Medicinische Bibliothek, ed. J. F. Blumenbach, Göttingen, Dieterich, 1791, vol. 3, pt. 3, p. 534.

23. Withering, W., Phil. Trans. R. Soc. Lond., 1784, 74, 293-311.

24. WIthering, W., An Account of the Foxglove, and some of its Medical Uses, Birmingham, G. G. J. and J. Robinson, 1785.

25. PARKeS, op. cit., p. 317.

26. MATHER, A., Medical Commentaries, 1794, 9, 265-70.

27. Miscellanea, No. 8, J. Sci. Arts, 1818, 4, 382.

28. Blyth, A. W., Poisons: Their Effects and Detection, London, Griffin, 1884, pp. 642-47. 


\section{G. D. Schott}

29. Quoted by Wrtrtaus, R. A., Manual of Toxicology, 2nd ed., London, Baillière, Tindall \& Cox, 1911, pp. 682-85. A comprehensive review of cases of barium poisoning up to about 1911 is included amongst the references.

30. Annotation, Pharm. J., 1868 (2nd series), 10, 181-82.

31. Annotation, ibid., 1872 (3rd series), 2, 1021.

32. Annotation, ibid., 1936 (4th series, 82), 136, 641.

33. Edwards, E. G., J. Amer. med. Assoc., 1910, 54, $46-47$.

34. Graham, C. F., ibid., 1934, 102, 1471.

35. TIDY, C. M., Med. Press, $1868,6,447-48$.

36. WIIson, Lond. med. Gaz., 1834, 14, 487-90.

37. SeIDEL, M., Vjschr. gericht. Med. off. SanitWes., N.F., 1877, 27, 213-21.

38. HIGIER, H., Dt. Z. NervHeilk., 1922, 73, 336-45.

39. An excellent account of the historical aspects of familial periodic paralysis is given in the review article by J. H. Talbot, Medicine, Baltimore, 1941, 20, 85-143.

40. Huang, K. W., Chin. med. J., 1943, 61, 305-12.

41. Allen, A. S., ibid., 1943, 61, 296-301.

42. Diengott, D., Rozsa, O., LeVy, N. and Muammur, S., Lancet, 1964, ii, 343-44.

43. Schott, G. D. and McArdle, B., J. Neurol. Neurosurg. Psychiat., [in press].

44. Editorial, Lancet, 1894, ii, 1237-39.

45. Morton, W., ibid., 1945, ii, 738-39.

46. LEWI, Z. and BAR-KHAYIM, Y., ibid., 1964, ii, 342-43.

47. Compton, A., ibid., 1946, i, 287.

48. Brodir, B. C., Phil. Trans. R. Soc. Lond., 1812, 102, 205-27.

49. Orfila, M. P., Traité des Poisons, Paris, Crochard, 1814, vol. 1, pt. 2, pp. 167-82; Anonymous English translation: M. P. Orfila, A General System of Toxicology, London, Cox, 1816, vol. 1, pt. 2, pp. 389-401.

50. BLAKE, J., Edinb. med. surg. J., 1841, 56, 104-24.

51. Blake, J., J. Anat. Physiol., Lond., 1874, (2nd series, 7), 8, $243-49$.

52. Quoted by Higier, op. cit., p. 341.

53. Brunton, T. L. and CASH, J. T., Phil. Trans. R. Soc. Lond., 1884, 175, 197-244.

54. RINGer, S. and SAINSBURY, H., Br. med. J., 1883, ii, 265-68.

55. Editorial, Lancet, 1888, i, 1311-12.

56. HARe, H. A., Med. News, Philadelphia, 1889, 54, 183; quoted in the Lancet Editorial, 1894, op. cit., and by A. C. Crawford, see ref. 71.

57. Corn, A. E. and Levine, S. A., Archs. intern. Med., 1925, 36, 1-12.

58. Rothierger, C. J. and Winterberg, H., Pflügers Arch. ges. Physiol., 1911, 142, 461-522.

59. GmelnN, C. G., Versuche über die Wirkungen des Baryts . . . auf den thierischen Organismus, Tübingen, Laupp, 1824, pp. 8-15.

60. Bовнм, R., Arch. exp. Path. Pharmak., 1875, 3, 216-51.

61. Onsum, J., Virchows Arch. path. Anat. Physiol., 1863, 28, 233-37.

62. Cyon, M., Arch. Anat. Physiol., 1866, 196-203.

63. Smith, P. K., Winkler, A. W. and Hof, H. E., J. Pharmac. exp. Ther., 1940, 68, 113-22.

64. Arrigoni, A., Medna Lav., 1933, 24, 461-68; quoted by: D. Hunter in The Diseases of Occupations, 5th ed., London, English Universities Press, 1969, pp. $1054-55$.

65. Cannon, W. B., Amer. J. Physiol., 1898, 1, 359-82.

66. KAestLe, C., Münch. med. Wschr., 1908, 55, 2666-67.

67. BACHEM, C. and GüNTHER, H., Z. Röntgenk. Radiumforsch., 1910, 12, 369-76.

68. Quoted by BrUwer, A. J., in Classic Descriptions in Diagnostic Roentgenology, Springfield and Fort Lauderdale, Thomas, 1964, vol. 2, p. 1873.

69. Annotation, Lancet, 1919, i, 943-44.

70. Dean, G., Br. med. J., 1950, ii, 817-18.

71. Crawford, A. C., Bull. Bur. Pl. Ind. U.S. Dep. Agric., 1908, 129, 1-87. 
Some Observations on the History of the Use of Barium Salts in Medicine

72. Editorial, J. Amer. med. Assoc., 1908, 51, 1338.

73. Holmes, E. M., Pharm. J., 1891, (3rd series), 21, 1149-50.

74. Candolle, A. P. De, Physiologie Végétale, Paris, Béchet, 1832, vol. 3, p. 1341.

75. Welt, L. G. and Blythe, W. B., 'Cations, calcium, magnesium, barium, lithium and ammonium', in The Pharmacological Basis of Therapeutics, 4th ed., (eds. L. S. Goodman and A. Gilman), London and Toronto, Macmillan, 1970, p. 814.

76. Lydtin, H., Kusus, T., Dietze, G. and Schnelle, K., Arzneimittel-Forsch., 1967, 17, 1456-59. 